\title{
Induced sputum in adolescents with severe stable asthma. Safety and the relationship of cell counts and eosinophil cationic protein to clinical severity
}

\author{
D.C. Grootendorst***, J-W. van den Bos*, J.J. Romeijn*, M. Veselic-Charvat ${ }^{+}$, E.J. Duiverman*, \\ E.J.L.E. Vrijlandt ${ }^{\#,}$, P.J. Sterk**, A.C. Roldaan*
}

Induced sputum in adolescents with severe stable asthma. Safety and the relationship of cell counts and eosinophil cationic protein to clinical severity. D.C. Grootendorst, J-W. van den Bos, J.J. Romeijn, M. Veselic-Charvat, E.J. Duiverman, E.J.L.E. Vrijlandt, P.J. Sterk, A.C. Roldaan. (C)ERS Journals Ltd 1999.

ABSTRACT: This study examined the safety of sputum induction and the relation between sputum cell counts and clinical parameters in adolescents with severe persistent asthma.

Within 5 days, induced sputum and reversibility in forced expiratory volume in one second (FEV1), quality of life, provocative concentration causing a $20 \%$ fall in FEV1 (PC20) of adenosine monophosphate and histamine, exercise-induced bronchoconstriction, overall asthma severity index, and blood eosinophils were collected in 20 atopic adolescents with moderate-to-severe persistent asthma (12-18 yrs of age, FEV1 $65-110 \%$ of predicted, on $500-2,000 \mu \mathrm{g}$ inhaled steroids daily).

FEV1 was reversible by $13.3 \pm \mathbf{2 . 3} \%$ pred. After sputum induction, FEV1 was still increased by $9.0 \pm 2.6 \%$ pred as compared to the pre-salbutamol baseline. Sputum contained, median (range): $12.4(0.4-59.5) \%$ squamous cells, $47.3(6.8-84.0) \%$ macrophages, $39.0(4.6-84.8) \%$ neutrophils, $4.8(1.0-12.4) \%$ lymphocytes, $0.4(0-10.8) \%$ eosinophils and $3.6(0-23.4) \%$ bronchial epithelial cells. Sputum eosinophils showed a trend towards a significant association with the overall asthma severity index $(r=0.46$, $p=0.06)$ and correlated inversely with baseline FEV1 $(r=-0.51, p=0.03)$.

In conclusion, sputum can be induced safely in adolescents with moderate-to-severe persistent asthma, if pretreated with $\beta_{2}$-agonists. Despite relatively low sputum eosinophil counts in these patients on inhaled steroids, the association of eosinophil numbers with baseline forced expiratory volume in one second and asthma severity index favours a role of induced sputum in monitoring adolescents with severe asthma. Eur Respir J 1999; 13: 647-653.

Asthma is a chronic disease, characterized by ongoing inflammation in the airways [1]. Studies using bronchial biopsies and bronchoalveolar lavage have demonstrated increased infiltration of eosinophils, mast cells and lymphocytes in the airways of subjects with asthma [2]. However, bronchoscopy is an invasive procedure, especially in children, and use is therefore restricted to adult patients with mild forms of asthma [3].

Induced sputum is currently considered to be a noninvasive alternative to bronchoscopy to examine airways inflammation. Induced sputum has been shown to yield reproducible data with regard to cellular and soluble markers of inflammation in asthmatic and healthy subjects as well as in smokers with chronic nonobstructive bronchitis $[4,5]$. In subjects with asthma, induced sputum is characterized by increased numbers of eosinophils and mast cells as compared to sputum from healthy subjects $[6,7]$. Naturally occurring acute exacerbations of asthma are associated with further increases of eosinophil [8] or neutrophil numbers [9]. In addition, eosinophil and neutrophil counts are elevated in induced sputum $24 \mathrm{~h}$ after an allergen challenge [10,11], while treatment of asthmatic subjects with oral or inhaled corticosteroids (ICS) decreases the number of sputum eosinophils $[12,13]$.
*Dutch Asthma Centre, Davos, Switzerland. Depts of **Pulmonology and ${ }^{+} \mathrm{Pa}-$ thology, Leiden University Medical Centre, Leiden, the Netherlands. Juliana Children's Hospital, The Hague, the $\mathrm{Ne}-$ therlands. "Medisch Spectrum Twente Hospital, Enschede, The Netherlands.

\section{Correspondence: D.C. Grootendorst Lung Function Laboratory C2-P Dept of Pulmonology \\ Leiden University Medical Centre P.O. Box 9600 \\ NL-2300 RC Leiden \\ The Netherlands \\ Fax: 31715154691}

Keywords: Asthma severity eosinophils

sputum induction

Received: February 91998

Accepted after revision October 201998

Supported by Stichting Astma Bestrijding, and Sensormedics, the Netherlands, and ASTRA, Switzerland.
When considering the relationship between sputum and airway physiology, it has been demonstrated that eosinophils and eosinophil cationic protein (ECP) in sputum are correlated with the degree of airway obstruction and symptom scores $[6,14,15]$. In addition, eosinophils in sputum are associated with bronchial hyperresponsiveness (BHR) when measured by methacholine [14] or histamine [15], but not by hypertonic saline [16]. Moreover, it has been shown in subjects with asthma that eosinophil numbers in sputum reflect those in bronchial washings, bronchoalveolar lavage fluid, and bronchial biopsies [17, 18]. These studies support the view that induction of sputum can be used to monitor airway inflammation in subjects with asthma.

While its noninvasive properties make it a potentially very useful tool to study airway inflammation in children and adolescents with asthma, very few studies on induced sputum have been conducted in this group. PIN et al. [19] have shown that in children with symptomatic mild asthma, sputum eosinophils are increased as compared to healthy children and children with asymptomatic asthma, with no statistical difference in sputum eosinophils between the latter two groups. In children with an acute exacerbation of asthma, induced sputum is characterized 
by increased numbers of eosinophils, neutrophils and mast cells, which decrease again with resolution of the exacerbation [20]. So far, studies on induced sputum in relatively severe asthmatic children are lacking.

The aim of this study was to examine the safety of sputum induction in atopic adolescents with moderate-tosevere persistent asthma, and, secondly, to examine whether cell numbers in induced sputum are related to clinical parameters in this group of patients. To this end, 20 atopic asthmatic adolescents were examined in a cross-sectional study. Sputum was induced by inhalation of hypertonic saline in these atopic asthmatics. Differential cell counts obtained from whole processed sputum samples were related to diary card outcomes, quality-of-life scores, degree and reversibility of airways obstruction, BHR to different stimuli, markers of inflammation in blood and an overall index of asthma severity.

\section{Methods}

\section{Patients}

Twenty nonsmoking, atopic adolescents with asthma, optimally treated with moderate-to-very-high dose ICS [21], were invited to participate in this study (12 male, mean \pm SEM age $14.9 \pm 0.4$ yrs (table 1$)$ ). The mean \pm SEM dose of ICS in this group of patients was $1,295 \pm 113.7 \mu \mathrm{g}$ of fluticasone $(n=17)$, budesonide $(n=2)$ or beclomethasone $(\mathrm{n}=1)$ daily (range 500-2,000 $\mu \mathrm{g})$. Based on these levels of inhaled steroids, patients were characterized as having moderate or severe persistent asthma [22]. In addition to ICS, long-acting $\beta_{2}$-agonists were used by 17 of the patients, while all of them used short-acting $\beta_{2}$-agonists for relief of symptoms. All patients had to have a forced expiratory volume in one second (FEV1) $>60 \%$ of predicted $[23,24]$, BHR to inhaled histamine as shown by a provocative concentration causing $20 \%$ fall in FEV1 (PC20) of $\leq 8 \mathrm{mg} \cdot \mathrm{mL}^{-1}$ [25], and atopy as indicated by a positive radioallergosorbent test (RAST; score $>2$ ). None of the patients had had symptoms of a respiratory tract infection within the four weeks prior to the study.

\section{Design}

All patients attended the laboratory on three consecutive days. At the first visit, blood was drawn and the paediatric asthma quality-of-life questionnaire (PAQLQ) was completed. BHR to adenosine monophosphate (AMP) was measured in the morning, followed $4 \mathrm{~h}$ after spontaneous recovery by a bronchial provocation with histamine. A standardized exercise challenge was performed on day 2 . Reversibility of FEV1 to salbutamol was measured prior to sputum induction at the third visit. All patients were instructed to record morning and evening peak expiratory flow (PEF) rates and day- and night-time symptoms in a diary card for a 5-day period, commencing 2 days before the first challenge test until the day of sputum induction. Theophyllines, nedocromil and long-acting $\beta_{2}$-agonists

Table 1. - Subject characteristics

\begin{tabular}{|c|c|c|c|c|c|c|c|c|c|c|c|c|c|c|}
\hline Subj. & $\begin{array}{l}\text { Age } \\
\text { yrs }\end{array}$ & $\begin{array}{l}\text { FEV1 } \\
\% \text { pred }\end{array}$ & $\begin{array}{l}\text { Revers } \\
\% \text { pred }\end{array}$ & $\begin{array}{l}\mathrm{PC} 20, \mathrm{AMP} \\
\mathrm{mg} \cdot \mathrm{mL}^{-1} *\end{array}$ & $\begin{array}{l}\mathrm{PC} 20, \mathrm{HIST} \\
\mathrm{mg} \cdot \mathrm{mL}^{-1} *\end{array}$ & $\begin{array}{c}\text { EIB } \\
\text { max\% } \\
\text { fall }\end{array}$ & $\begin{array}{l}\text { PEFm } \\
\text { \%pred }\end{array}$ & $\begin{array}{l}P E F_{v} \\
\text { amp } \\
\% \text { mean }\end{array}$ & CSS & ASI & QoL & $\begin{array}{l}\text { Blood } \\
\text { eos. } \\
\times 10^{6} \cdot \mathrm{L}^{-1}\end{array}$ & $\begin{array}{c}\% \\
\text { Sputum } \\
\text { eos. }\end{array}$ & Medication \\
\hline 1 & 15 & 60.5 & 20.2 & 6.4 & 0.13 & 25.0 & 66.0 & 1.3 & 20 & 10 & 5.9 & 395 & 5.8 & $1000 \mathrm{~F}, \mathrm{~S}$ \\
\hline 2 & 17 & 61.5 & 24.4 & 19.2 & 0.22 & 20.4 & 51.4 & 16.4 & 24 & 11 & 5.0 & 1316 & 5.6 & $1500 \mathrm{~F}, \mathrm{Fo}$ \\
\hline 3 & 17 & 66.3 & 32.0 & 0.08 & 0.015 & 60.0 & 75.5 & 12.7 & 37 & 12 & 4.0 & 472 & 3.2 & $1000 \mathrm{~F}, 600 \mathrm{~T}, \mathrm{~S}$ \\
\hline 4 & 17 & 72.1 & 12.2 & 51.1 & 1.05 & 15.2 & 91.1 & 12.4 & 25 & 7 & 6.4 & 291 & 0 & $1600 \mathrm{~B}$ \\
\hline 5 & 15 & 72.7 & 12.8 & 19.6 & 0.21 & 16.3 & 68.7 & 7.4 & 26 & 10 & 5.7 & 700 & 0 & $1500 \mathrm{~F}$ \\
\hline 6 & 14 & 72.8 & 8.8 & 2.7 & 0.08 & 45.7 & NA & NA & NA & ND & 4.3 & 1342 & - & $2000 \mathrm{~F}$ \\
\hline 7 & 15 & 82.0 & 8.6 & 160.0 & 1.3 & 5.6 & 83.0 & 8.1 & 25 & 6 & 6.5 & 322 & 0.4 & $1000 \mathrm{~F}, \mathrm{~S}$ \\
\hline 8 & 16 & 83.2 & 15.1 & 6.1 & 0.015 & 18.6 & 83.5 & 8.4 & 11 & 8 & 4.3 & 503 & 0.4 & $1000 \mathrm{~F}, \mathrm{~S}$ \\
\hline 9 & 18 & 85.0 & 6.3 & 126.4 & 0.25 & 8.8 & 92.2 & 7.2 & 6 & 7 & 5.4 & 31 & 1.6 & $2000 \mathrm{~F}, \mathrm{~S}$ \\
\hline 10 & 17 & 86.5 & 26.5 & 0.08 & 0.015 & 51.5 & 74.0 & 12.8 & 19 & 9 & 4.8 & 222 & 0 & $2000 \mathrm{~F}, \mathrm{~S}$ \\
\hline 11 & 13 & 89.8 & 7.5 & 28.3 & 0.2 & 15.5 & 90.8 & 13.9 & 20 & 8 & 5.5 & 625 & 2.8 & $1500 \mathrm{~F}, \mathrm{~S}$ \\
\hline 12 & 14 & 90.1 & 15.6 & 2.6 & 0.17 & 31.9 & 67.6 & 4.1 & 79 & 11 & 2.7 & 1045 & 10.8 & $1000 \mathrm{~F}, \mathrm{~S}$ \\
\hline 13 & 15 & 90.4 & 2.2 & 80.0 & 1.41 & NP & 72.5 & 3.4 & NA & ND & 4.0 & 134 & 5.8 & $2000 \mathrm{~F}, 60 \mathrm{P}, \mathrm{S}$ \\
\hline 14 & 14 & 93.0 & 25.6 & 170.4 & 0.04 & 27.6 & 64.4 & 18.9 & 4 & 7 & 3.3 & 855 & 0.2 & $1000 \mathrm{~F}, \mathrm{~S}$ \\
\hline 15 & 12 & 93.8 & 0 & 224.9 & 0.95 & 7.9 & 86.6 & 10.4 & 5 & 5 & 6.2 & 300 & 0 & $500 \mathrm{~F}, \mathrm{~S}$ \\
\hline 16 & 13 & 94.0 & 14.6 & 25.5 & 0 . & 9.1 & 78.4 & 6.6 & 5 & 6 & 6.6 & 272 & 5.0 & $1000 \mathrm{BDP}, 8 \mathrm{~N}, \mathrm{~S}$ \\
\hline 17 & 12 & 96.5 & 2.8 & 10.9 & 0.015 & 23.9 & 68.3 & 5.9 & 11 & 9 & 4.6 & 20 & 0 & $800 \mathrm{~B}, \mathrm{~S}$ \\
\hline 18 & 14 & 99.2 & 4.8 & 27.2 & 2.7 & 1.7 & 64.4 & 17.9 & 32 & 8 & 4.1 & 131 & 2.8 & $2000 \mathrm{~F}, 8 \mathrm{~N}, \mathrm{~S}$ \\
\hline 19 & 15 & 103.1 & 13.0 & 17.3 & 1.2 & 4.2 & NA & NA & NA & ND & 5.9 & 191 & 0 & $500 \mathrm{~F}, \mathrm{~S}$ \\
\hline 20 & 15 & 115.9 & 0 & 0.9 & 0.21 & 24.5 & 82.6 & 11.4 & 24 & 9 & 3.1 & 681 & 0.6 & $1000 \mathrm{~F}, \mathrm{~S}$ \\
\hline $\begin{array}{l}\text { Tean } \\
\text { EM) }\end{array}$ & $\begin{array}{l}14.9 \\
(0.4)\end{array}$ & $\begin{array}{l}85.4 \\
(3.2)\end{array}$ & $\begin{array}{l}13.3 \\
(2.3)\end{array}$ & $\begin{array}{l}12.2 \\
(0.7)\end{array}$ & $\begin{array}{c}0.19 \\
(0.5)\end{array}$ & $\begin{array}{l}21.8 \\
(3.7)\end{array}$ & $\begin{array}{l}75.6 \\
(2.7)\end{array}$ & $\begin{array}{l}10.0 \\
(1.2)\end{array}$ & $\begin{array}{l}22.6 \\
(4.5)\end{array}$ & $\begin{array}{c}8.4 \\
(0.5)\end{array}$ & $\begin{array}{c}4.9 \\
(0.3)\end{array}$ & $\begin{array}{c}322.0 \\
1.0-131\end{array}$ & $\begin{array}{r}0.4 \\
0-10.8)\end{array}$ & $\begin{array}{c}1295 \\
(113.7)\end{array}$ \\
\hline
\end{tabular}

Subj.: Subject; Revers: reversibility in forced expiratory volume in one second (FEV1), expressed as \% pred; PC20,AMP: provocative concentration of adenosine monophosphate causing a 20\% fall in FEV1; PC20,HIST: provocative concentration of histamine causing a $20 \%$ fall in FEV1; EIB: exercise-induced bronchoconstriction, expressed as maximal \% fall in FEV1; PEFm: mean mimimum morning peak expiratory flow, expressed as \% pred; PEFv: peak expiratory flow variability, expressed as amplitude \% mean; CSS: cumulative symptom score; ASI: asthma severity index; QoL: quality-of-life score; eos.: eosinophils. *: Geometric mean, sD in doubling doses; ${ }^{\dagger}$ : median (range). NA: data not available; ND: not determined due to incomplete diary cards; NP: not performed; F: fluticasone; B: budesonide; BDP: beclomethasone; T: theophylline; P: prednisone; N: nedocromil; S: salmeterol; Fo: formoterol. -: no sputum sample obtained during sputum induction. 
were discontinued from $48 \mathrm{~h}$ before the first challenge until after sputum induction at the third visit. Short-acting $\beta_{2}$ agonists were withheld for $8 \mathrm{~h}$ before each challenge test. In addition, patients were asked to refrain from caffeinecontaining beverages in the $4 \mathrm{~h}$ preceding challenges. The study was approved by the ethical committees of the participating hospitals. Informed consent was given by the adolescents and their guardians.

\section{Quality of life}

To assess the influence of asthma on day-to-day functioning (when the patients are using all their medication), the patients filled in the PAQLQ in the week prior to the study visits [26]. The PAQLQ contains five questions on activity limitation, 10 questions on symptoms and eight questions on emotional function. For each of the questions of the PAQLQ, patients were asked to recall which impairment they had experienced during the previous week. Response options were recorded on a 7-point scale where 1 indicates maximum impairment and 7 indicates no impairment. Results were expressed as mean score per domain and as the mean of all questions [26].

\section{Diary cards}

Diary cards were completed during the period that the patients were refraining from their long-acting bronchodilators, i.e. from 2 days before the first challenge test until the day of sputum induction. The best of three PEF measurements, as obtained with a mini-Wright peak flow meter, was recorded every morning and evening, before medication usage. Severity of daytime dyspnoea, cough, sputum production and limitation in activities, and nocturnal dyspnoea and cough were registered on a scale ranging 0 (no symptoms) to 3 . Diary cards were used to calculate the following parameters. The minimum morning PEF (PEFmin) was determined as the lowest PEF in the study period and expressed as \% pred [23]. Variation in PEF (PEFvar) was calculated as diurnal variation (highest minus lowest value as a percentage of the mean) averaged over the study period (amplitude \% mean). Scores for all symptoms during the 5-day period were added to yield a cumulative symptom score (CSS) ranging 0-90.

\section{Spirometry and challenge tests}

Flow-volume curves and FEV1 were recorded according to recommendations [24], using a Masterlab pneumotachograph (Jaeger, Würzburg, Germany) or a wet spirometer (Pulmonet3; Sensormatics, Bilthoven, the Netherlands). Results were compared to reference values for children and adolescents of QUANJER et al. [23].

Bronchial responsiveness to AMP (Merck, St Louis, MO, USA) in saline and to histamine diphosphate in phosphate-buffered saline were measured using the standardized 2 min tidal breathing method [25]. AMP and histamine solutions were administered to the patient in serial doubling concentrations ranging $0.15-320 \mathrm{mg}$ AMP. $\mathrm{mL}^{-1}$ and $0.03-8 \mathrm{mg}$ histamine $\cdot \mathrm{mL}^{-1}$, using a DeVilbiss 646 nebulizer (DeVilbiss Co., Somerset, PA, USA). With the method used, the normal ranges for AMP and histamine were $>320 \mathrm{mg} \cdot \mathrm{mL}^{-1}$ and $>8 \mathrm{mg} \cdot \mathrm{mL}^{-1}$, respectively $[25,27]$. After the last dose of AMP or histamine, spontaneous recovery of FEV1 was measured at 3, 5, 7, 10 and 15 min. If
FEV1 was not within $5 \%$ of baseline, measurements of FEV1 were continued at 20, 30, 45 and 60 min, until FEV1 was within $5 \%$ of baseline. PC 20 was calculated by linear interpolation of the last two points of the log concentrationresponse curves.

A standardized exercise challenge, with inhalation of compressed dry air $\left(20^{\circ} \mathrm{C}\right.$, relative humidity $\left.<15 \%\right)$ was performed on a bicycle ergometer (ER900; Jaeger or Sensormedics, Bilthoven, the Netherlands) according to recommendations [25]. The work intensity was gradually increased for each of the subjects to achieve a minute ventilation between 40 and $60 \%$ of their predicted maximal voluntary ventilation $(\mathrm{FEV} 1 \times 35)$ during the first $2 \mathrm{~min}$ of exercise. At this work intensity level, subjects exercised for 4 min. During exercise, ventilation was measured by a $V_{\max }$ (Sensormedics spirometer). FEV1 after exercise was measured regularly, using the time schedule as following the AMP or histamine challenge. The response to exercise was expressed as the maximal percentage fall in FEV1 from baseline value.

\section{Sputum induction}

Prior to sputum induction, FEV1 was measured before and $15 \mathrm{~min}$ after inhalation of $200 \mu \mathrm{g}$ salbutamol by a metered-dose inhaler (MDI) connected to an aerosol chamber, which was administered for safety reasons. The reversibility in FEV1 was calculated as the difference between post- and prebronchodilator FEV1, expressed as \% pred. Sputum was then induced by inhalation of hypertonic saline $(4.5 \%)$ aerosols $[4,17]$. Sodium chloride aerosols were generated at room tempreature by a DeVilbiss Ultraneb 2000 ultrasonic nebulizer at maximal output setting (2.5 $\left.\mathrm{mL} \cdot \mathrm{min}^{-1}\right)$. The generated aerosols have a particle size with a mass median aerodynamic diameter of $4.5 \mu \mathrm{m}$ [28]. Patients inhaled saline aerosols in periods of $5 \mathrm{~min}$ for a maximum of $15 \mathrm{~min}$. Every $5 \mathrm{~min}$, patients were asked to rinse their mouth and throat with water and to expectorate sputum into a clean plastic container. Sputum induction was discontinued if an adequate amount of sputum was produced (at least $0.5-1 \mathrm{~g}$ ), if the $15 \mathrm{~min}$ of inhalation was completed or if the patient experienced any discomfort. After completion of the procedure and whenever the subject felt uncomfortable, FEV1 was measured again. When FEV1 fell by $>20 \%$ from baseline during or after sputum induction, a final dose of $200 \mu \mathrm{g}$ sabutamol was administered using a pressurized MDI (pMDI).

\section{Sputum processing}

Whole sputum samples (sputum unseparated from saliva) were processed according to a published protocol [4, 17] in one centre within 2-4 h of sputum induction. In brief, a volume of $0.1 \%$ dithiothreitol (Sputolysin; Calbiochem, La Jolla, CA, USA), equal to the volume of the whole sputum sample, was added. Samples were gently mixed using a wide bore pipette, and placed in a shaking water bath at $37^{\circ} \mathrm{C}$ for $15 \mathrm{~min}$ to ensure complete homogenization. Homogenized sputum was centrifuged at $350 \times g$ for $10 \mathrm{~min}$. Supernatant was aspirated and stored at $-20^{\circ} \mathrm{C}$ pending analysis. Cell pellets were resuspended in phosphate-buffered saline and filtered through a nylon mesh (pore size $48 \mu \mathrm{m}$; Thompson, Ontario, Canada). Cell viability and total cell count were then established by 
trypan blue exclusion using a haemocytometer. Cytospin slides were prepared by cytocentrifugation for $3 \mathrm{~min}$ at $250 \times g$, with a cell suspension containing $0.5-1.0 \times 10^{6}$ cells $\cdot \mathrm{mL}^{-1}$ (Shandon cytocentrifuge 3; Shandon Southern Instruments, Sewickley, PA, USA). Differential cell counts were made by a qualified cytologist, on coded MayGrünwald-Giemsa stained cytospins and expressed as percentage of 500 cells, excluding squamous cells. Furthermore, absolute cell counts were calculated as the number of cells $\cdot \mathrm{mL}^{-1}$. Sputum samples containing $>80 \%$ squamous cells were excluded from analysis because of poor cytospin quality [4].

\section{Blood eosinophils and ECP}

Peripheral blood eosinophils were counted by an automated counter and expressed as total cells. $\mathrm{L}^{-1}$. Serum was separated after allowing the samples to stand for $1 \mathrm{~h}$ and centrifugation at $925 \times g$ for $10 \mathrm{~min}$. ECP in sputum supernatants and serum was determined by radioimmunoassay (Pharmacia, Uppsala, Sweden) and expressed as ng. $\mathrm{mL}^{-1}$.

\section{Overall asthma severity index}

The above measurements were used to calculate an overall asthma severity index. This was based on cumulative symptom score (CSS), medication usage, baseline FEV1 and $\mathrm{PC}_{20}$ of histamine, each of those arbitrarily being divided into five categories [21, 29] (table 2). The overall asthma severity index was calculated as the sum of the five categories from the four variables, and could thus range from 0 to 16 .

\section{Analysis}

Baseline FEV1 was calculated as the mean of the morning FEV1 on the three consecutive study days. Change in FEV1 after sputum induction was calculated as the difference between FEV1 recorded after sputum induction and pre-salbutamol FEV1, expressed as \% pred. Owing to their highly skewed distribution, data on PC20 of AMP and PC20 of histamine, percentage eosinophils, neutrophils and

Table 2. - Categories for asthma medication usage [21], cumulative symptom score (CSS), baseline forced expiratory volume in one second $\left(\mathrm{FEV}_{1}\right)$ and provocative concentration of histamine causing a $20 \%$ fall in FEV 1 (PC20) to calculate the overall asthma severity index

\begin{tabular}{|c|c|c|c|c|}
\hline $\begin{array}{l}\text { Cate- } \\
\text { gory }\end{array}$ & Medication & CSS* & $\begin{array}{l}\text { FEV1 } \\
\% \text { pred }\end{array}$ & $\begin{array}{l}\mathrm{PC} 20 \\
\mathrm{mg} \cdot \mathrm{mL}^{-1}\end{array}$ \\
\hline 0 & $\beta_{2}$-agonists only & $0-5$ & $>80$ & $>8$ \\
\hline 1 & Low dose $\mathrm{ICS}^{\dagger}$ & $6-20$ & $70-80$ & $4-8$ \\
\hline 2 & Moderate $^{\star}$-high dose $\operatorname{ICS}^{\S}$ & $21-40$ & $60-70$ & $1-4$ \\
\hline 3 & $\begin{array}{l}\text { High-very high dose } \text { ICS }^{\#} \\
\pm \text { oral steroids }\end{array}$ & $41-60$ & $50-60$ & $0.25-1$ \\
\hline 4 & $\begin{array}{c}\text { Very high dose ICS + oral } \\
\text { steroids + additional } \\
\text { therapy }\end{array}$ & $>60$ & $<50$ & $<0.25$ \\
\hline
\end{tabular}

*: CSS obtained from the diary cards; ${ }^{\dagger}$ : low dose inhaled corticosteroids (ICS), beclomethasone dipropionate (BDP) $\leq 500$ $\mu \mathrm{g}$, fluticasone $(\mathrm{FP}) \leq 250 \mu \mathrm{g}$, budesonide $(\mathrm{Bu}) \leq 400 \mu \mathrm{g}$ daily; $\because$ moderate dose ICS, BDP $500-1,000 \mu \mathrm{g}$, FP $250-500 \mu \mathrm{g}$, Bu 400-800 $\mu \mathrm{g}$ daily; ${ }^{\S}$ : high dose ICS, BDP $1,000-2,000 \mu \mathrm{g}$, FP 500-1,000 $\mu \mathrm{g}$, Bu 800-1,600 $\mu \mathrm{g}$ daily; \#: very high dose ICS, FP 1,000-2,000 $\mu \mathrm{g}$, Bu 1,600-3,200 $\mu \mathrm{g}$ daily. bronchial epithelial cells in sputum, eosinophil counts in blood, ECP levels in serum and sputum, and CSS, were log-transformed before analysis. Since the non-normally distributed variables contained zeros, the value of one was added to all data prior to log-transformation. Data are presented as mean \pm SEM or, in cases of non-normal distribution, as median (range). Correlations between sputum eosinophils, neutrophils and ECP on the one hand and clinical parameters on the other were tested using the parametric technique of Pearson. Analyses were performed with the Statistical Package for Social Sciences (SPSSPC+; SPSS, Chicago, IL, USA). A p-value <0.05 was considered significant.

\section{Results}

One patient had a progressive fall in FEV1 (>20\% pred) when measuring baseline spirometry, and PC20 values for AMP and histamine were arbitrarily set at 0.15 and 0.015 $\mathrm{mg} \cdot \mathrm{mL}^{-1}$, respectively. Exercise could not be performed in one patient, whereas it resulted in a fall in FEV1 of $>60 \%$ from baseline requiring rescue medication in one other patient, so that recovery in FEV1 could not be measured. Diary cards were completed by 17 patients. Clinical and lung function data are shown in table 1, and sputum and blood contents in table 3 . There was a close correlation between the overall asthma severity index and PC20 of AMP $(r=-0.70, p<0.01)$, exercise-induced bronchoconstriction (EIB) expressed as the maximum \% fall in FEV1 $(\mathrm{r}=0.67, \mathrm{p}<0.01), \%$ eosinophils in blood $(\mathrm{r}=0.54, \mathrm{p}<$ $0.05)$, PEFmin $(r=-0.55, \mathrm{p}<0.05)$ and paediatric qualityof-life score $(\mathrm{r}=-0.51, \mathrm{p}<0.05)$.

\section{Lung function during and after sputum induction}

Inhalation of hypertonic saline was well tolerated by all adolescents. The mean \pm SEM duration of sputum induction was $11.7 \pm 0.8 \mathrm{~min}$. The mean and individual FEV1 before and after salbutamol pretreatment and after sputum induction are shown in figure 1. The individual changes in FEV1 after sputum induction as compared to the presalbutamol baseline value ranged between an increase of $30.2 \%$ pred and a decrease of $12.6 \%$ pred. The percentage change in FEV1 after sputum induction was significantly correlated with pre-salbutamol baseline FEV1 in $\%$ pred $(\mathrm{r}=-0.57, \mathrm{p}<0.01)$, reversibility in FEV1 $(\mathrm{r}=$

Table 3. - Total cell count, viability, differential cell count and eosinophil cationic protein (ECP) in induced sputum, and eosinophils and ECP in blood

\begin{tabular}{lcc}
\hline & Induced sputum & Blood \\
\hline Total cell count & $9.0(0.5-71.0)$ & \\
$\times 10^{6} \cdot \mathrm{mL}^{-1}$ & & \\
Viability \% & $85.3(52.9-98.2)$ & \\
\% squamous cells & $12.4(0.4-59.5)$ & \\
$\%$ macrophages & $47.3(6.8-84.0)$ & \\
$\%$ neutrophils & $39.0(4.6-84.8)$ & \\
\% eosinophils* & $0.4(0-10.8)$ & $358.5(31.0-1342.0)$ \\
\% lymphocytes & $4.8(1.0-12.4)$ & \\
$\%$ bronchial & $3.6(0-23.4)$ & \\
epithelial cells & & \\
ECP ng.mL & & \\
\hline
\end{tabular}

Data are presented as median (range). ${ }^{*}$ : Eosinophils in blood are presented as number of cells $\times 10^{6} \cdot \mathrm{mL}^{-1}$. 


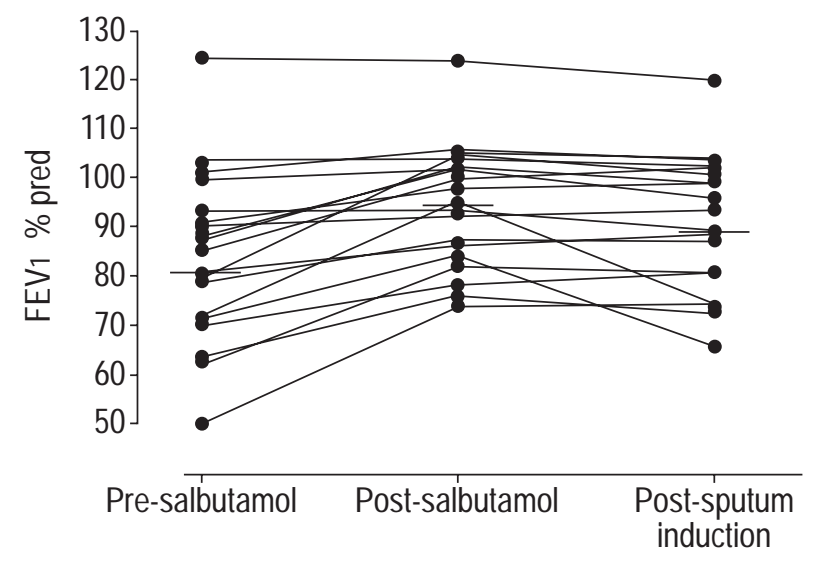

Fig. 1. - Forced expiratory volume in one second (FEV1) as measured before and after salbutamol pretreatment and after sputum induction. Prior to sputum induction, baseline FEV1 increased significantly from mean \pm SEM $83.0 \pm 3.9 \%$ pred to $95.3 \pm 3.1 \%$ pred $(\mathrm{p}<0.001)$ after salbutamol. After sputum induction, FEV1 was $91.3 \pm 3.3 \%$ pred, which was significantly better as compared to pre-salbutamol baseline ( $p=$ 0.001). Horizontal bars represent the mean of all samples.

$0.74, \mathrm{p}<0.01)$ and $\mathrm{PC} 20$ of histamine $(\mathrm{r}=-0.49, \mathrm{p}<0.05)$, with a trend towards such a correlation with peripheral blood eosinophils $(r=0.45, p=0.053)$.

Sputum induction did not have any bronchoconstrictive effects after the monitoring period since neither PEF rates on the evening, nor the morning following sputum induction, were different from PEF rates on the morning prior to sputum induction $(\mathrm{p}>0.1)$.

\section{Induced sputum samples}

Sputum was induced successfully in 19 of the patients, whereas one patient was unable to cough up a sputum sample within the $15 \mathrm{~min}$ induction period. Mean and individual total cell counts, viability, \% squamous cells, differential cell count and ECP levels in sputum supernatants are presented in table 3 . Sputum differential cell counts and ECP did not correlate with lung function or airway hyperresponsiveness, or with the diary card outcomes or quality of life. However, there was a trend towards a correlation between $\%$ eosinophils in sputum and asthma severity index ( $r=0.46, \mathrm{p}=0.06$; fig. 2$)$. In addition,

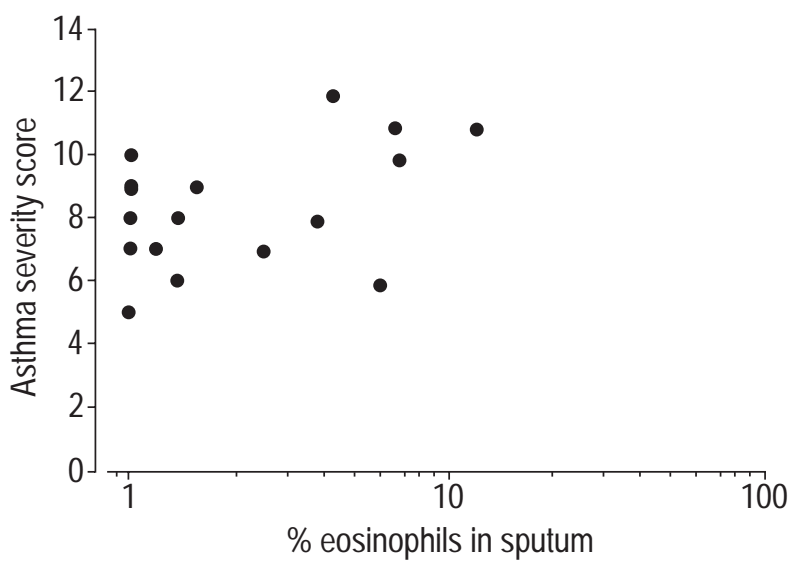

Fig. 2. - The relationship between the percentage sputum eosinophils and the asthma severity score. Eosinophils in induced sputum borderline significantly correlated with the asthma severity score $(\mathrm{r}=0.46, \mathrm{p}=0.06)$.

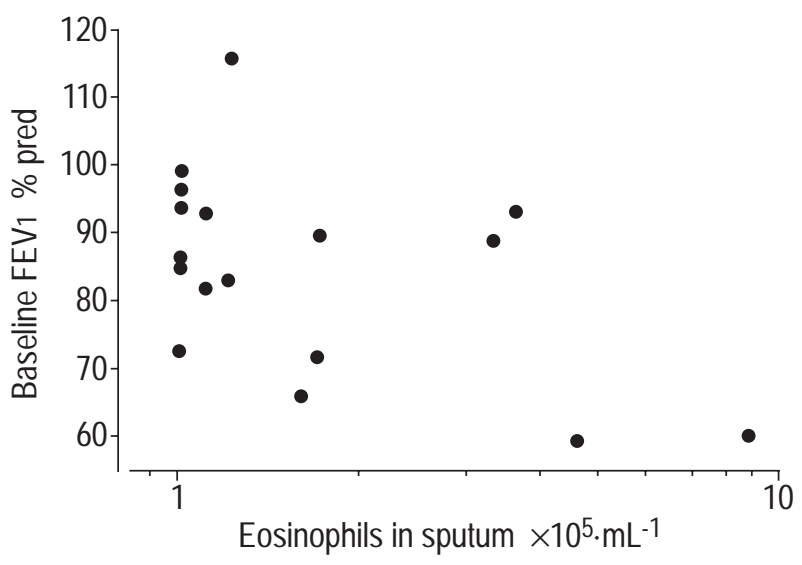

Fig. 3. - The relationship between absolute sputum eosinophil counts in induced sputum and baseline forced expiratory volume in one second (FEV1). Eosinophil numbers in induced sputum correlated inversely with baseline FEV1 $(r=-0.51, p=0.03)$.

absolute numbers of eosinophils in sputum correlated with baseline FEV1 ( $\mathrm{r}=-0.51, \mathrm{p}=0.047$; fig. 3). Eosinophils and neutrophils in sputum correlated with ECP levels in sputum supernatant $(r=0.60, p<0.01$ and $r=0.68$, $\mathrm{p}<0.01$, respectively). Sputum eosinophils were weakly associated with blood eosinophil numbers $(\mathrm{r}=0.43, \mathrm{p}=$ 0.09 ). Furthermore, there was a trend towards correlation between sputum and serum ECP levels $(r=0.43, \mathrm{p}=0.06)$.

\section{Discussion}

This study shows that sputum can be induced safely and successfully in adolescents with moderate-to-severe persistent asthma who are currently treated with high-dose ICS. The sputum induction procedure did not result in clinically significant bronchoconstriction after pretreatment with $200 \mu \mathrm{g}$ inhaled salbutamol. Sputum samples of these steroid-treated patients contained few \% eosinophils which were, nevertheless, correlated with ECP levels in sputum supernatant and baseline FEV1, with a similar trend for asthma severity index. These results suggest that induction of sputum by inhalation of $4.5 \%$ hypertonic saline is an easily applicable, noninvasive and safe method to study airway inflammation in patients with moderate-tosevere persistent asthma, aged between 12 and 18 yrs. Induced sputum samples may yield additional information in the monitoring of these patients.

To the authors' knowledge, this is the first study examining the safety and validity of sputum induction by inhalation of hypertonic saline aerosols in atopic asthmatic teenagers with moderate-to-severe persistent asthma. In 19 of these patients, $<15 \mathrm{~min}$ inhalation was enough to yield a sputum sample. When patients were pretreated with salbutamol, FEV1 at the end of sputum induction was still increased as compared to pre-salbutamol baseline in the majority of patients. Interestingly, none of the patients experienced a drop in FEV1 after sputum induction $>13 \%$ pred and such a drop appeared to develop only in those patients with a relatively high baseline FEV1 and with the smallest response to inhaled salbutamol. Indeed, the change in FEV1 after sputum induction was inversely related to pre-salbutamol baseline FEV1 and PC20 histamine, and positively correlated with reversibility in FEV1. This indicates that patients with the greatest reversibility in 
airways obstruction are best protected by $\beta_{2}$-agonists against potential bronchoconstrictive effects of inhaling hypertonic saline during sputum induction. These results confirm and extend those of Wong et al. [30] although these authors' also observed a relationship between the change in FEV1 after sputum induction and sputum eosinophils, which could not be demonstrated in the present patients.

The present results were obtained using standardized and validated techniques. Firstly, patients with asthma, using moderate-to-very-high dose ICS regularly to control the disease [21], were selected from the outpatient departments of several hospitals. All patients were seen at 6month intervals by their treating specialist. Patients were treated for their asthma according to recent guidelines and ICS dosages were reduced stepwise to the lowest dose at which symptoms were controlled [31]. Patients were thus treated by an optimal dose of ICS. Secondly, BHR was measured to an indirect stimulus (AMP), as well as to a direct stimulus (histamine), on the same day, in order to minimize the number of study days. This was justified by the observation that BHR to histamine measured after an AMP challenge was not different from before [32]. Thirdly, in order to validate the safety of sputum induction, FEV1 measured directly after completion of the sputum induction procedure was compared to the pre-salbutamol baseline value instead of to the post-salbutamol FEV1 as carried out by Wong et al. [30]. The current authors believe that this approach is clinically more relevant because any worsening in FEV1 after the procedure is being related to the patients real baseline FEV1. Fourthly, the method used in this study to induce and process sputum has been validated extensively [4]. Fifthly, the PAQLQ is a recently developed questionnaire to establish asthma-related quality of life in children aged between 7 and $17 \mathrm{yrs}$ [26]. The questionnaire is reproducible in Canadian children and teenagers with stable asthma and is able to detect changes in patients whose asthma improves or deteriorates [26]. The officially translated Dutch version of the PAQLQ was used in the present study. Although validation of the Dutch version of the questionnaire in a Dutch population has not been published yet, it can be assumed that cultural differences between Canadian and Dutch children are relatively small and unlikely to interfere with validity or responsiveness of the questionnaire. Finally, a score for overall asthma severity was calculated based on current treatment level, level of baseline FEV1, level of symptoms and level of hyperresponsiveness to histamine (table 2) [21]. This apparently yielded a representative score for severity of asthma since it correlated with the bronchoconstrictive response to exercise, and peripheral blood and sputum eosinophils, while it correlated inversely with BHR to AMP, PEFmin and quality of life.

Percentages of sputum eosinophils in this study appeared to be low, in particular when taking into account the level of symptoms and BHR to histamine in these patients and when comparing the sputum eosinophils numbers to those in healthy children (median \% sputum eosinophils 0.15) [19]. It has been shown by PiAcENTINI et al. [33] that induced sputum in asthmatic children contains $10.8 \%$ eosinophils. However, most of these children were treated with low-to-moderate doses of inhaled beclomethasone, which was discontinued in the week before collection of induced sputum. Since treatment with inhaled steroids results in a decrease in sputum eosinophils [13], withdrawal of asthma medication in the latter studies might have resulted in an increase in eosinophil numbers in sputum. The relatively low eosinophil counts in the present study may suggest that the adolescents were adequately treated with inhaled steroids and were compliant to their therapy, resulting in suppressed inflammation within the airway lumen. Indeed, sputum samples obtained from teenagers with mild stable asthma with or without symptoms, not requiring regular treatment, contains only $1.7 \%$ and $0.4 \%$ eosinophils, respectively [19]. It should be noted that absence of luminal inflammation in these patients with asthma using moderate-to-very-high dose ICS, does not neccessarily mean that mucosal inflammation is equally suppressed. Although it has previously been shown that sputum eosinophils may reflect the number of tissue eosinophils, subjects with no eosinophils in sputum may still have a considerable variation in mucosal eosinophil number $[17,18]$.

Despite the relatively low eosinophil numbers in sputum, these cells were shown to be associated with baseline FEV1 and asthma severity score, which is in accordance with previous studies $[6,14,15]$. In addition, it was demonstrated that eosinophils in sputum are related to ECP levels in sputum supernatants, suggesting activation of those cells within the airways. Surprisingly, such a correlation could also be demonstrated for sputum neutrophils. Recent in vitro experiments have shown that neutrophilderived proteases such as elastase can cause eosinophil degranulation [34], which may explain the observed relation between sputum neutrophils and ECP.

What are the clinical implications of the present results? Induction of sputum by inhalation of hypertonic saline aerosols is a safe procedure in teenagers with moderate-tosevere persistent asthma, provided that they are pretreated with an adequate amount of inhaled bronchodilator. Sputum induction is apparently an easily applicable and welltolerated method for studying airway inflammation in this age group of asthmatic patients. In this cross-sectional analysis, cell numbers in induced sputum appeared to be associated with the degree of airway obstruction, but not with bronchial hyperresponsiveness, diary card outcomes or quality of life. It is, therefore, likely that examining airway inflammation in induced sputum samples provides complementary information on top of symptoms and lung function, which may be useful in long-term monitoring of adolescent patients with severe asthma. Obviously, this needs to be examined in careful prospective studies.

\footnotetext{
Acknowledgements. The authors wish to thank N. van Eik, H. Oosterom, E. Oostveen and M. de Graaf for their technical assistance and hospitality at their lung function departments; $T$. van Essel for performing all ECP measurements; and E. Juniper, from McMaster University, Hamilton, Canada, for providing us with the Dutch version of the paediatric asthma quality-of-life questionnaire.
}

\section{References}

1. Djukanovic R, Roche WR, Wilson JW, et al. Mucosal inflammation in asthma. Am Rev Respir Dis 1990; 142: 434-457.

2. Poston RN, Chanez P, Lee TH, Lacoste JY, Litchfield T, Bousquet J. Immunohistochemical characterization of the 
cellular infiltration in asthmatic bronchi. Am Rev Respir Dis 1992; 145: 918-921.

3. Jeffery PK. Bronchial biopsies and airway inflammation. Eur Respir J 1996; 9: 1583-1587.

4. In't Veen JCCM, de Gouw HWFM, Smits HH, et al. Repeatability of cellular and soluble markers of inflammation in induced sputum from patients with asthma. Eur Respir J 1996; 9: 2441-2447.

5. Pizzichini E, Pizzichini MMM, Efthimiadis A, et al. Indices of airway inflammation in induced sputum: reproducibility and validity of cell and fluid-phase measurements. Am J Respir Crit Care Med 1996; 154: 308-317.

6. Pin I, Gibson PG, Kolendowicz R, et al. Use of induced sputum cell counts to investigate airway inflammation in asthma. Thorax 1992; 47: 25-29.

7. Fahy JV, Liu J, Wong H, Boushey HA. Cellular and biochemical analysis of induced sputum from asthmatic and from healthy subjects. Am Rev Respir Dis 1993; 147: $1126-1131$.

8. Gibson PG, Girgis-Gabardo A, Morris MM, et al. Cellular characteristics of sputum from patients with asthma and chronic bronchitis. Thorax 1989; 44: 693-699.

9. Fahy JV, Woo Kim K, Liu J, Boushey HA. Prominent neutrophilic inflammation in sputum from subjects with asthma exacerbation. J Allergy Clin Immunol 1995; 95: 843-852.

10. Fahy JV, Liu J, Wong H, Boushey HA. Analysis of cellular and biochemical constituents of induced sputum after allergen challenge: a method for studying allergic airway inflammation. J Allergy Clin Immunol 1994; 93: 1031-1039.

11. Pin I, Freitag AP, O'Byrne PM, et al. Changes in the cellular profile of induced sputum after allergen-induced asthmatic responses. Am Rev Respir Dis 1992; 145: $1265-1269$.

12. Claman DM, Boushey HA, Liu J, Wong H, Fahy JV. Analysis of induced sputum to examine the effects of prednisone on airway inflammation in asthmatic subjects. J Allergy Clin Immunol 1994; 94: 861-869.

13. Jatakanon A, Lim S, O'Connor BJ, Chung KF, Barnes PJ. Inhaled budesonide improves non-invasive markers of airway inflammation in asymptomatic steroid naive asthmatic patients. Am J Respir Crit Care Med 1997; 155: A288.

14. Pizzichini E, Pizzichini MMM, Efthimiadis A, Dolovich J, Hargreave FE. Measuring airway inflammation in asthma: eosinophils and eosinophil cationic protein in induced sputum compared with peripheral blood. $J \mathrm{Al}$ lergy Clin Immunol 1997; 99: 539-544.

15. Ronchi MC, Piragino C, Rosi E, Amendola M, Duranti R, Scano G. Role of sputum differential cell count in detecting airway inflammation in patients with chronic bronchial asthma or COPD. Thorax 1996; 51: 1000-1004.

16. Iredale MJ, Wanklyn SAR, Phillips IP, Krausz T, Ind PW. Non-invasive assessment of bronchial inflammation in asthma: no correlation between eosinophilia of induced sputum and bronchial responsiveness to inhaled hypertonic saline. Clin Exp Allergy 1994; 24: 940-945.

17. Grootendorst DC, Sont JK, Willems LNA, et al. Comparison of inflammatory cell counts in asthma: induced sputum versus bronchoalveolar lavage and bronchial biopsies. Clin Exp Allergy 1997; 27: 769-779.

18. Maestrelli P, Saetta M, Di Stefano A, et al. Comparison of leukocyte counts in sputum, bronchial biopsies, and bronchoalveolar lavage. Am J Respir Crit Care Med 1995; 152: 1926-1931.
19. Pin I, Radford S, Kolendowicz R, et al. Airway inflammation in symptomatic and asymptomatic children with methacholine hyperresponsiveness. Eur Respir $J$ 1993; 6: 1249-1256.

20. Twaddell SH, Gibson PG, Carty K, Woolley KL, Henry RL. Assessment of airway inflammation in children with acute asthma using induced sputum. Eur Respir J 1996; 9: 2104-2108.

21. Cockcroft DW, Swystun VA. Asthma control versus asthma severity. J Allergy Clin Immunol 1996; 98: 10161018.

22. National Heart Lung and Blood Institute. National Asthma Education and Prevention Program. Expert Panel Report 2: Guidelines for the Diagnosis and Management of Asthma. NIH publication no. 97-4051. Bethesda, MD, USA, 1997.

23. Quanjer PhH, Borsboom GJJM, Brunekreef B, et al. Spirometric reference values for white European children and adolescents: Polgar revisited. Pediatr Pulmonol 1995; 19: 135-142.

24. Quanjer PhH, Tammeling GJ, Cotes JE, Pedersen OF, Peslin R, Yernault J-C. Lung volumes and forced ventilatory flows. Eur Respir J 1993; 6: Suppl. 16, 5-40.

25. Sterk PJ, Fabbri LM, Quanjer PhH, et al. Airway responsiveness. Standardized challenge testing with pharmacological, physical and sensitizing stimuli in adults. Eur Respir J 1993; 6: Suppl. 16, 53-83.

26. Juniper EF, Guyatt GH, Feeny DH, Ferrie PJ, Griffith LE, Townsend M. Measuring quality of life in children with asthma. Qual Life Res 1996; 5: 35-46.

27. Oosterhoff Y, de Jong JW, Jansen MAM, Koeter GH, Postma DS. Airway responsiveness to adenosine 5'monophosphate in chronic obstructive pulmonary disease is determined by smoking. Am Rev Respir Dis 1993; 147: 553-558.

28. Leigh TR, Nazir T, Wiggins J, Ganderton O, Collins JV. Performance characteristics of the DeVilbiss Ultraneb 99 ultrasonic nebuliser. Thorax 1990; 45: 817 (abstract).

29. Woolcock AJ, Jenkins CR. Assessment of bronchial responsiveness as a guide to prognosis and therapy in asthma. Med Clin N Am 1990; 74: 753-765.

30. Wong HA, Fahy JV. Safety of one method of sputum induction in asthmatic subjects. Am J Respir Crit Care Med 1997; 156: 299-303.

31. The British Thoracic Society, The National Asthma Campaign, The Royal College of Physicians of London in association with the General Practitioner in Asthma Group, the British Association of Accident and Emergency Medicine, the British Paediatric Respiratory Society and the Royal College of Paediatrics and Child Health. The British guidelines on asthma management 1995 review and position statement. Thorax 1997; 52 (Suppl. 1): S1-S21.

32. Phillips GD, Bagga PK, Djukanovic R, Holgate ST. The influence of refractoriness to adenosine $5^{\prime}$-monophosphate on allergen-provoked bronchoconstriction in asthma. Am Rev Respir Dis 1989; 140: 321-326.

33. Piacentini GL, Martinati L, Mingoni S, Boner AL. Influence of allergen avoidance on the eosinophil phase of airway inflammation in children with allergic asthma. $J$ Allergy Clin Immunol 1996; 97: 1079-1084.

34. Liu H, Lazarus SC, Caughey G, Fahy JV. Neutrophil elastase degranulates eosinophils in vitro. Am J Respir Crit Care Med 1997; 155: A67. 